\title{
THE WEALTH CONCEPT. A STUDY IN ECONOMIC THEORY.
}

"Nothing," says a recent writer, 1 " can be more fundamental in economic science than the conception of wealth." The student of economic literature finds a striking unanimity among writers, since the publication of the Wealth of Nations, that the real purpose of every treatise on this science is to investigate the nature and the laws of wealth. It would appear to be a logical prerequisite, therefore, that every writer on economic science should have a definite conception of what is meant by wealth.

But is such the case? What student has not learned to his sorrow that the most careful study of economic literature is unable to satisfy him exactly what wealth is?

Adam Smith wrote An Inquiry into the Nature and Causes of the Wealth of Nations, and yet made no attempt to define wealth. It may have appeared to him unnecessary to define scientifically that of which every one seemed to have a conception sufficiently clear. But had he made the attempt at that stage of the development of society and of the sciences which pertain to it, he would have found it difficult to formulate a scientific definition of wealth.

Nearly three-quarters of a century of unprecedented economic, social, and political development had elapsed, when John Stuart Mill published his Principles of Political Economy, and lent the weight of his great authority to the statement: "Every one has a notion sufficiently

1 John B. Clark, Philosophy of Wealth (1886), p. 2. 
correct for common purposes of what is meant by wealth." 1 Although this statement would seem to imply the futility of all attempts to define the popular notion, even Mr. Mill found it necessary to attempt such a definition. Yet, to the reader's surprise, he has hardly formulated a definition, to which his authority would have given so much weight, when directly and with the same authority he condemns it. ${ }^{2}$

The student finds the evidence overwhelming that economic writers, from Adam Smith down, have not had a notion of wealth sufficiently definite for scientific purposes. The great diversity of fundamental principles is confusing to the reader, and has contributed more than anything else to close the portals of this grand science not only to many a would-be student, but more completely to the general reading public. There is a widespread conviction today that economic science exists simply for the specialist, and that even to him it is a matter of blind tradition, with no consistent principle to guide it; an arsenal of sophistry, out of which arguments may be drawn to fortify any and every position. For this mistaken notion the specialist is largely responsible. The highest interests of society call for the wide diffusion of the principles of economic science. Whatever may be said of the attractiveness of practical questions, the scientific spirit of the age demands that the fundamental conceptions of economic science shall be settled. Besides, as a recent writer ${ }^{3}$ has aptly said, practical subjects cannot be adequately discussed so long as obscurity still hangs over fundamental conceptions, the clear apprehension of which is absolutely essential to all correct reasoning.

Whether from a scientific or practical point of view, therefore, there can be no doubt that unanimity in the use

1 John Stuart Mill, Principles of Political Economy, Vol. I. p. I8. (D. Appleton \& Co., 1884.)

2 Vide this article, p. 618.

3 John B. Clark, Philosophy of Wealth, p. $\mathrm{x}$. 
of so important a term as wealth is not only desirable but imperative. But would an attempt to secure such unanimity be practicable and, therefore, timely? Confident that such an attempt, made in the light of recent investigations, is practicable, the writer does not hesitate in the following pages to reopen the discussion of wealth.

By way of apology for the obscurity of their fundamental conceptions, economists ${ }^{2}$ have been too fond of dwelling on the obstacles which their science encounters in the use of terms derived from the vocabulary of everyday life. Wealth is such a term. They congratulate the natural scientist, who can employ terms of his own invention, and lament that their own science must make use of the vague terms of popular speech. There is strong evidence that economists are beginning to realize that this so-called difficulty is largely apparent. They have been compelled, of late, to recognize the necessity for more careful analysis. In their efforts to formulate a scientific definition of a popular term like wealth, economists should, by no means, ignore the universal popular notion of which Mr. Mill writes. That popular notion is the block of marble out of which the scientific conception must be chiselled. Lying in the quarry of popular speech, its outlines are vague and indefinite. Under the chisel of careful analysis, however, there emerges from the shapeless mass the clear outline of a scientific conception. Only by careful analysis can the popular notion of wealth be made the guide to scientific truth.

What, then, is the universal popular notion of wealth of which Mr. Mill writes?

In popular speech wealth and money are employed as synonymous terms. Men of large wealth are commonly spoken of as "moneyed men." If we would catechise business men, to the query: What do you understand by

1 Walker, Political Economy, 2d edition, p. 30 (I887). Price, Chapters on Practical Political Economy, pp. 8, 9, and Io. Perry, An Introduction to Political Economy (1887), p. 20. 
wealth ? the ordinary reply would be "money." To continue the catechism, does this mean that business men commonly entertain the Mercantilist doctrine that wealth consists solely of money, and that nothing is wealth which is not money; that if a person owns one hundred dollars in money and a farm worth ten thousand dollars, his wealth is one hundred dollars? "Certainly not," is the reply, "in this case the person's wealth is ten thousand one hundred dollars. Wealth is money, and anything else which can be converted into money. In common speech, wealth is always expressed in terms of money."

We have carried our catechism far enough to show that there is a something, with which money has to do, which, according to the popular notion, constitutes the substance of wealth.

Now, before we subject this popular notion to scientific analysis, let us pause for a moment to note some of the current definitions of wealth.

"Wealth," says John Stuart Mill, " may be defined all useful and agreeable things which possess exchangeable value; or, in other words, all useful and agreeable things, except those which may be obtained in the quantity desired without labor or sacrifice." Furthermore, Mr. Mill writes: "In common discourse, wealth is always expressed in terms of money." Thus far Mr. Mill's definition of wealth seems, even in its indefiniteness, to be in full accord with the popular notion. A few pages later, however, with the statement: "It is essential to the idea of wealth to be susceptible of accumulation," Mr. Mill condemned the logic of his definition by drawing an arbitrary line to exclude from the category of wealth "things which cannot, after being produced, be kept for some time before being used"; as he thought that such things were never regarded as wealth. ${ }^{4}$ The essence of this definition, together

1 Principles of Political Economy, Vol. I. p. 26.

2 Ibid., Vol. I. p. 20.

3 Ibid., Vol. I. p. 75 .

4 Ibid., Vol. I. p, 75. Clack, Philosophy of Wealth, pp. 4, 5, and 6. 
with the illogical restriction of the same, Mr. Mill may be justly said to have inherited from Adam Smith. ${ }^{1}$ The influence of the Wealth of Nations upon Mr. Mill is further traceable in an illogical extension of his definition. "The skill and energy and perseverance of the artisans of a country," continues Mr. Mill, " are reckoned part of its wealth no less than their tools and machinery." Yet it is clearly evident that physical and mental characteristics and moral qualities do not possess "exchangeable value." As it is the peculiar province of political economy to investigate the relations of man, organized in society, to his material environment, there is no more mischievous error to be found in the whole range of economic literature than this one, which confounds the physical and mental characteristics and moral qualities of man with the material things to be derived from the outside world, objects of man's effort and sources of the gratification of his needs. Mr. Mill was conscious that such an extension of his definition would do violence to popular usage, and, therefore, in his Principles of Political Economy he uses the term in the restricted sense of material wealth as distinguished from non-material or personal wealth.

If we examine the works of recent text-writers for their conceptions of wealth, we shall find that some ${ }^{3}$ reject the term altogether; as "the word wealth has never been simply and exactly defined";" others, like Professors Fawcett and Marshall, follow Mr. Mill literally, accepting his definition illogically restricted and extended; while others, like President Francis A. Walker, without attempting an analysis of wealth, seem to be in accord with Mr. Mill's definition minus its modifications. "Wealth," says

1 Adam Smith, Wealth of Nations (Roger's edition), Vol. I. pp. 273-283.

2 Ibid., Vol. I. p. 75. Essays on some Unsettled Questions of Political Economy, Essay III.

3 Bastiat, The Harmonies of Political Economy (Stirling's translation), Part I. ch. III. Perry, Elements of Political Economy, pp. 42 and 43.

4 Perry, An Introduction to Political Economy, p. 20. 
President Walker," "comprises all articles of value and nothing else." As he makes no mention of Mr. Mill's illogical restriction of his definition, it is fair to infer that President Walker does not regard "susceptibility of accumulation" as the open door to the category of wealth. President Walker, however, expressly declines ${ }^{2}$ to classify physical and mental characteristics and moral qualities as wealth, as such things are not transferable and, consequently, do not possess value.

The analyses of Professor J. B. Clark have done much to prepare the way for a scientific use of the term wealth. Pointing out, with faultless logic, how the orthodox writers have unduly limited their conception of wealth in one direction and unduly extended it in another, Professor Clark has clearly revealed the full logical consequences of $\mathrm{Mr}$. Mill's simple definition. His analyses have done away with that sophistical classification of labor as productive and unproductive, by which such persons as "the actor, the musical performer, the public declaimer or reciter, and the showman" are excluded from the list of productive laborers. He says: " "Whether avowed or not, a definite conception is, in reality, under discussion in every treatise on this science. For this conception the term wealth, if used in the strictest accordance with history and etymology, is an accurate designation. The Saxon weal indicated a condition of relative well-being, the state of having one's wants well supplied as compared with a prevailing standard. No possession common to all men can constitute such relative well-being. The limitless gifts of nature do not produce it, since they are indiscriminating in their ministrations; air and sunlight make no differences among men, and, though creating absolute well-being, cannot create that social condition indicated by the term wealth. This relative condition can be produced only by that which,

1 Political Economy, p. 5.

2 Ibid., p. 7.

3 Philosophy of Wealth, pp. 3 and 4 . 
besides satisfying wants, is capable of appropriation. It is by a transfer of meaning that the term, which primarily designated a condition of life, has been applied to the things which produce the condition. But not all causes of comparative happiness are included in the meaning of the word. Wealth, as historically used, signified the well-being resulting from outward rather than from inward causes. Health and contentment may make the shepherd happier than the owner of flocks, yet the owner only is 'well off.' Reserving a broader term to designate well-being in general, usage has employed the word wealth to signify, first, the comparative welfare resulting from material possession, and, secondly, and by a transfer, the possessions themselves." His analysis brought him to the following definition: "Wealth consists in the relative-weal-constituting elements in man's material environment. It is objective to the user, material, useful, and appropriable." Professor Clark has been eminently successful in that which he undertook, namely, to elucidate the thought underlying the current definitions of wealth. But the student turns from the comparative study of the definitions of President Walker and Professor Clark with the feeling that, while the terms of the definitions differ, the underlying thought is at least, logically, the same.

But what do these definitions define? Do they define the universal popular notion (of wealth)? Even Professor Clark would make this the test of their scientific accuracy. "Who would claim," he writes," "that the subtle intuitions that determine the ordinary use of terms are not a guide to scientific truth?"

On the surface, it would appear that the economist had succeeded in defining the popular notion of wealth. But let us subject that notion to analysis. If we examine the expression of the popular notion of wealth, which our catechism of business men has elicited, shall we not find

I Philosophy of Wealth, p. 72. 
that the terms, taken literally, involve an inconsistency? Shall we not find two distinct conceptions for which the term wealth is used? In the first place, wealth is said to consist of money and of anything else which can be converted into money? Are not such things evidently "articles of value, and nothing else"? Are they not relative-weal-constituting elements in man's material environment; objective to the user, material, useful, and appropriable? Thus far, surely, the economist's definition accords well with the expression of the popular notion. Again, wealth, in popular speech, is said to be expressed in terms of money. But concrete articles of value in man's material environment, like areas of land, buildings, cattle, bushels of wheat, etc., are no more expressible in dollars and cents than in feet and inches or in pounds and ounces. If wealth is expressible in dollars and cents-and it certainly is according to the popular notion-concrete articles of value cannot be wealth any more than they can be length or weight. In this case, concrete articles are the containers of wealth; wealth is the content. If, according to the popular notion, wealth is expressible in dollars and cents, value must be the substance of wealth. Concrete articles possess, besides physical properties, the economic quality of utility or usefulness, for satisfying the needs of man, and the measure of that quality we call value. The dollar is our unit of value for measuring value, as the foot is our unit of length for measuring linear extension. We can no more measure and express in dollars and cents anything else than value than we can measure and express in feet and inches anything else than linear extension. Consciously or unconsciously we as surely apply the dollar to the value of the articles we posses or purchase as the salesman applies the yard to the cloth he sells.

Even economic writers, in spite of all their efforts to formulate a scientific definition of the term wealth, are guilty of the same inconsistency in its use. In fact, they more frequently use the term in some other sense than 
that which is conveyed by their definition. Does not President Walker fail to use the term wealth consistently with his definition? According to his definition, concrete articles of value are wealth. Later, in his discussion of production, he says ${ }^{1}$ that "the production of wealth means the creation of values"; that "wealth is produced whenever value is added or acquired through any act or any process." Here the term wealth is used to designate the value of concrete articles, which can be expressed in dollars and cents. To be consistent with his definition ought he not rather to have said, that the production of wealth means the bringing forth of new articles of value; that wealth is produced whenever through any act or any process new articles are added to the already existing list of valuable articles. His definition would evidently exclude from production all those acts and processes by which concrete articles already valuable receive an increment of value without undergoing any change in their essential character.

Does not Professor Clark, in his Philosophy of Wealth, use the term inconsistently with his definition? According to his definition, wealth consists of concrete articles of value: the "relative-weal-constituting elements in man's material environment," like wheat and clothing and implements. But, says Professor Clark, " "If a farmer, having surplus wheat, sells it for an equivalent in clothing and implements, his wealth changes its form of embodiment but not its amount." . The term wealth is evidently used here to signify an abstract quantum of value expressible in dollars and cents which, through the transaction, has changed its form of embodiment, but not its amount. To interpret the term wealth here by Professor Clark's definition of it would be to render the statement itself not true. The farmer's wheat would neither change its form of embodiment nor its amount, but as a result of the trans- 
action the farmer would have, in the place of the wheat, entirely different articles.

Does not Roscher reveal the same inconsistency even in his definition? The writer has before him the eleventh (1873) and seventeenth (1882) editions of Roscher's Grindlagen der Nationalökonomie. An interval of nine years had elapsed between the two editions of this great work. In the former, ${ }^{1}$ the author defines wealth as follows: "Wealth is the sum of all the economic goods comprised in the property of a physical or juridicial person." In the latter edition, ${ }^{2}$ he adds to this definition the following restricting clause: "After all debts have been deducted and all valuable claims have been added." It is evident that debts and claims always represent definite quantities of value. Is it not as impossible to deduct value from anything else than value as to deduct feet and inches from anything else than linear extension? How can Roscher deduct quantities of value from concrete things which go to make up a person's property?

But let us return to our analysis of the popular notion of wealth. We have reached the point where it seems to us clear that the language of popular speech is inconsistent, and that this inconsistency has become absorbed into the works of economic writers. Can we not explain this inconsistency? Shall we not find that what appears to be an inconsistency is only an instructive leaf of history? Is it not another illustration of the persistency of a term, while the conception, which it represents, has been constantly changing with the development of society?. Is not Professor Clark right that the term wealth, if used in the strictest accordance with history and etymology, is an accurate designation for that definite conception which is, in reality, under discussion in every treatise on economic science?

But Professor Clark, while his analysis is correct so far

1 System der Volkswirthschaft, Vol. I. p. 13,

2 Ibid., Vol. I. p. I 4 . 
as it goes, has failed to bring the history of the term wealth down to date. $\mathrm{He}$ has dropped the narrative, before reaching the period in which social differentiation had been carried so far, through the principle of division of labor, as to reveal the interdependence of men in economic relations and the organic nature of society. Does not his own logic compel him to go a step farther?

In that earlier period of the development of economic society, when each business establishment was an economic unit, independent of every other, organized to produce simply those things which were to be used in the business or consumed by the personnel of the establishment, the term wealth signified simply material possessions. Social differentiation had barely commenced, and the organic structure of society in industrial relations was not apparent. Men thought simply of the relation of concrete articles to their own individual use. The rearing of flocks, the tilling of the soil, the practising of the hand trades, had for their aim to provide such articles. There were, to be sure, different conditions of "relative well-being" then as now; but concrete articles constituted the only basis for comparing one man's condition with that of another. They were the only "relative-weal-constituting elements." The man who owned land and buildings, or flocks, was "better off" in the estimation of other men than the man who owned nothing; the man who owned a larger flock was more "well to do" than he who owned a smaller. A bountiful harvest contributed to the "relative well-oeing" of the husbandman. Man's wants were few. In general men labored to obtain, each for himself, the same varieties of articles. These were few in number to correspond to man's wants. A person's wealth, therefore, could be ascertained only by taking an inventory of the concrete articles he owned. The amount of a person's wealth could be stated only in terms of area, weight, or number.

How different the situation in that later period of the development of economic society whose chief character- 
istic is universal interdependence of parts ; production and consumption for others. To-day it is clearly evident that the structure of industrial society is organic. Political science and statesmanship, all of the sciences and arts which pertain to society, recognize the great fact that society is an organic unit. Is not the economist, who has too often taken things by bits and scraps, compelled to recognize the same great fact, and from that vantageground to look at the whole of the complicated interests of industrial society in one connected view? Has not the popular notion of wealth adjusted itself to the organic nature of industrial society? Can the economist define wealth without the comprehensive view which the conception of society as an organism affords?

The individual is no longer industrially independent; he no longer exists and labors simply for himself and those dependent upon him. Social differentiation has made him part of a living structure, an organism. So close is his dependence upon others of his race that his conduct is dictated and his nature transformed by it. In existing and laboring for himself he exists and labors for the social organism. He goes into business not to produce specific articles for his own use, as formerly, but a quantum of value. The specific articles produced are turned into the general market, and to the general market each man must go to obtain the articles required to satisfy his own needs. The individual estimates the product of his business not so much in pounds, feet, or dozens, as in dollars and cents. The participants in production share no longer the concrete articles manufactured, but a quantum of value. The laborer receives, as his share, not the yard of cloth he weaves, but the value he creates. A person's power to command from the general market the necessaries, comforts, and luxuries of life is in direct ratio to the quantum of value he controls. The condition of "relative well-

1 Clark, Philosophy of Wealth, pp. $37,3^{8}, 39,40$, and 4 r. 
being" of the members of the social organism, therefore, is produced not by the ownership of concrete articles, but by the ownership of a quantum of value. The thousand cases of shoes do not determine the owner's position on the scale of "relative well-being"; they can ward off neither hunger nor cold. The value which they possess is the "relative-weal-constituting element." The knowledge that one man owns a factory and another man a farm does not enable us to compare their economic conditions. A man may own a given thousand bushels of wheat to-day and a month hence, but there is no surety that his condition of "relative well-being" will remain unchanged. A rise or decline in the value of wheat raises or lowers his position in the scale of "relative well-being." A man may be a rich man to-day and a poor man to-morrow, and yet be owner of the same concrete articles. It cannot be denied that social differentiation has changed the conception of wealth. A person's wealth cannot be ascertained now, as formerly, by taking an inventory of the concrete articles he owns. Wealth no longer signifies material possessions. Value is the substance of wealth.

To prove this let us continue our catechism of business men. Enumerate to a business man the concrete articles owned by a certain person with whom he is not acquainted; assure him, if you will, that he owns, free from debt, one hundred acres of land, ten houses, five horses, etc., and then ask him if he knows what the person's wealth is. Would he not reply, in substance, as follows: "Certainly not; you have enumerated to me the concrete forms in which the person's wealth is embodied; but I cannot know his wealth until I know the value of all those things. The land and houses may be located in the heart of a flourishing city or in some declining hill town, the horses may contain a 'Maud S.,' or they may be all worn-out hack horses. Tell me, in dollars and cents, what all those things would bring in the market, and I know the person's wealth. It 
is a matter of comparative indifference in what particular form the wealth may be embodied."

But value ${ }^{1}$ is a generic term, and there are two species with which the student is familiar. It is imperative, therefore, that the writer should explain more definitely in what sense he uses the term value when he says that value constitutes the substance of wealth.

The individual, though a member of the social organism, still retains his individual character. He is dependent, primarily, upon his own exertions for the satisfaction of his needs, although the specific articles he makes flow into the general market, and from the general market he obtains the articles he wishes to use. Social differentiation has brought it about that every individual must bargain with the social organism for the things he wishes to use. To every legitimate transaction in the market, therefore, the individual is one party; society is the other. The social organism is a unit, and we speak, in a collective sense, of its needs, as we do of the needs of the individual member of that organism. There are two standpoints, therefore, which the economist must recognize in studying the relation of man to his material environment: the standpoint of society and the standpoint of the individual. From the former, he acquires the conception of value to society ("value in exchange," " market value"), and from the latter, the conception of value to the individual ("value in use"). To find the "exchange value" of concrete articles one must measure their "effective" 2 utility to the social organism; while to find the "value in use" of concrete articles the individual must measure their "effective" utility to himself. Only in the light of these two species of value can any legitimate transaction in the market be explained. The salesman acts as, the agent of

1 For full particulars of value, vide: Karl Knies, Tübinger Zeitschrift, 1855 . Karl Knies, Das Geld, II. Auflage, I885, pp. I67 and 168. J. B. Clark, Philosophy of Wealth, ch. V.

2 J. B. Clark, Philosophy of Wealth, pp. 77 and 78. 
the social organism, and having measured the "exchange value" of his loaf, offers it to the millionaire and the day laborer at the same price. No one can deny that the "value in use" of the loaf to the day laborer is much greater than to the millionaire. But the social organism is no respecter of persons. If the would-be consumer buys, he must buy at the terms which society imposes; whether he buys or not rests entirely with himself. No prudent man buys, unless, in his judgment, the "value in use" of the article is greater than, or at least equal to its "exchange value." "Value in use," therefore, determines where in the social organism the concrete articles in the market shall be used, while "value in exchange" fixes the conditions under which they may be obtained. How else can we explain the fact that we pass by, in the market, so many articles truly desirable; others we give only a wistful glance; others we ponder long and decide slowly to purchase or not to purchase, while for others the bargain is quickly made. "Value in use" is individual, and no man can estimate for any one but himself. "Value in use," therefore, can furnish no standard for comparing one man's condition of "relative well-being" with that of another; it cannot be the substance of wealth. The old homestead, which has been the family pride for generations, does not contribute to the wealth of the owner to the extent of one hundred thousand dollars, although the owner may estimate its value to him at that figure. That particular homestead can be to no one else what it is to him. In economic relations, the social organism is rarely influenced by sentiment. In the market the old homestead is worth twenty-five hundred dollars, and must be rated at that figure if one would compare the owner's economic condition with that of his neighbors. A projected highway takes from the old homestead a strip of land. No one, but the owner, thinks the loss irreparable. For, in spite of the loss of the half acre, the value of the homestead to society is greater than before, and the owner is "better 
off" in the estimate of his neighbors. Although a large sum would be no temptation to a man to part with the lock of hair he so carefully guards, his only possession besides the clothes he wears, the lock of hair contributes nothing to his wealth. To society the lock of hair possesses no value. It is only from the standpoint of society that it becomes possible to compare one man's economic condition with that of other men. A man's economic condition can only be determined by estimating the quantum of "exchange value" that belongs to him. "Exchange value," therefore, is the only "relative-weal-constituting element"; it is the substance of wealth both according to the popular notion and using the term in the strictest accordance with history and etymology.

Wealth, according to this definition, is equally acceptable to all men. But this individual has a decided preference in regard to the form of embodiment of his wealth. His purpose, in entering the market, is to change the form of its embodiment, but not to change its amount. If the exchange is a fair one, his wealth is left without increase or diminution. But, as a means to an end, there has arisen one universally acceptable form of embodiment for wealth, namely, metallic money. For that reason, if for no other, he who prefers to have a part of his wealth in some new concrete articles readily accepts money as the most convenient means to that end. The traveller takes the wealth for his journey in the form of money. For the consumer, money is the key which most easily unlocks the market. At some time, the business man prefers his capital in the form of money, that he may more readily choose the instruments with which to work. It is, indeed, not strange that wealth and money, in popular speech, are synonymous terms.

We have traced the evolution of the wealth concept. We have attempted to show that the conception of wealth, which the current definitions define, belongs to an earlier period of economic development; that the proces of social 
differentiation, which has rendered the structure of industrial society organic, has wrought a change in the conception of wealth; that the term wealth to-day signifies no longer concrete articles but a quantum of exchange value.

An important corollary follows from our analysis. It is evident that the whole question of production is relative to the period of economic development. When wealth signified concrete articles of value, production was the bringing forth of new articles of value. All labor was directed toward that end. No labor was productive which did not add to the existing list of valuable articles. There was little division of labor, no commercial class, "no legislator, judge, or officer of justice." But when social differentiation had given rise to a commercial class, to the army and navy, to the legislator, judge, and the officer of justice, there came into existence a class of men who, according to the current conception of wealth, must be regarded as unproductive. Their activities, however useful and important they might be, resulted in no new concrete articles. With their conception of wealth the classic philosophers, and Church Fathers, who were unable to find a legitimate basis for commercial activities, were more logical than modern economists. On the basis of the conception that wealth is concrete, it is impossible to prove to the satisfaction of the logical mind, that all labor in modern society creates wealth. But this is exactly what economists have attempted to do, and there are no chapters in economic science more unsatisfactory than those which treat of the relation of labor to wealth. For the production of wealth, in all periods of economic development nature has always furnished the substance and man the modes. Social differentiation has not only changed the conception of wealth, but it has multiplied the modes of producing wealth. With the organic conception of wealth as a quantum of exchange value, it becomes evident that any acts or any processes which result in an increase of the existing quantum of "exchange value" are productive 
of wealth. Every man can select that mode for creating wealth for which he is best adapted by nature. The mode he selects may be one which results in a concrete article of no use to himself. He can trust the social organism to place at his disposal the specific articles he wishes to use, of better quality and cheaper than he could have made them himself. No demonstration is needed to prove that the commercial class, the army and navy, the legislator, judge, and officer of justice increase directly the quantum of "exchange value," and are therefore productive. Is it not time to star as obsolete that conception of wealth which our text-books define and put in its place the organic conception of wealth?

It is not necessary to show that the problem of distribution in modern society is based on the organic conception of wealth. It is evident to every one that it is the new quantum of exchange value created that is shared by the participants in production.

But another important corollary follows from our analysis. The evolution of the wealth concept has wrought a change in the relation of wealth to property. ${ }^{1}$ Property is a legal term and signifies the right of a person to control over a concrete thing to the exclusion of all other persons. It is not an absolute right, but is defined by law and has been modified from time to time to meet the requirements of progressive society. By transfer, the term property is used to denote the things over which a person has the right of exclusive control. Using the term in this sense, we see that a person's property can be found by taking an inventory of the concrete articles over which he exercises this right. At that period of industrial development when the term wealth signified concrete articles, the very same concrete articles were both wealth and property to their owner. They were wealth so far as they had a bearing on

1 Knies, Politische Oekonomie, II. Auflage (I883), pp. 208-2II. Knies, Das Geld, II. Auflage (1385), pp. 124-I40. 
the owner's economic condition; they were property so far as reference was had to the owner's right of control over them. Now that wealth has come to signify a quantum of "exchange value," without reference to its form of embodiment, we see that the relation of wealth to property has changed. A person's wealth is now the quantum of "exchange value" which belongs to him. A person's property comprises the concrete articles over which he has the right of exclusive control. The relation of wealth to property is not so close that a person's property must necessarily comprise the concrete articles which contain his wealth. Now that the custom of borrowing and loaning wealth has become prevalent, the concrete articles in which a person's wealth is contained may be the property of some other person. To determine a person's wealth, therefore, one must first ascertain the quantum of "exchange value" his property contains, and then deduct all debts and add all valuable claims. We thus see that a person may hold the right of property in land, buildings, and implements, and yet possess little or no wealth; for while the concrete articles may belong to the property of one person, the quantum of exchange value they contain may belong to the wealth of another.

To every man wealth is the sacred thing, because it is the fruit of his labor. While he has a preference in regard to the particular concrete form in which he shall invest his wealth, yet that is a matter of far less importance to him. From the multiplicity of concrete articles in the market, he is sure to find something suited to his need. He chooses to have his wealth now in one form, later in another. $\mathrm{He}$ enters the market, not to change his wealth, but to change his property. Instead of so many bushels of wheat, he wishes implements and clothing. If the interests of society call for the surrender of a particular concrete article for the public good, the individual submits and recognizes the justice of the demand in case his wealth is left intact. 
634 Annals of the American Academy.

The concrete article is not the product of his labor; the value that it contains is. Let society guarantee to the individual his wealth, and the individual will be found ready to yield to public expediency in regard to the concrete articles which he may hold as his property.

Amherst College, Amherst, Mass.

Charles A. Tuttrle. 